Members of the Research Forum Associated Authors:

${ }^{1}$ Department of Horticulture, Faculty of Agriculture, Annamalai

University, Annamalainagar, Chidambaram (T.N.) India
Author for correspondence : E. Arivazhagan

Department of Horticulture, Faculty of Agriculture, Annamalai

University, Annamalainagar,

Chidambaram (T.N.) India

Email : arivu2@ rediffmail.com

\section{Influence of plant growth regulators on growth characters of brinjal (Solanum melongena L.) cv. ANNAMALAI}

\section{E. Arivazhagan, A. Kavitha ${ }^{1}$ and R. Kandasamy ${ }^{1}$}

ABSTRACT : A field experiment was carried out to study the effect of plant growth regulators on growth and yield of brinjal cv. ANNAMALAI. The growth regulators were applied in three different concentrations viz., NAA (25, 50 and $100 \mathrm{ppm}), \mathrm{GA}_{3}(50,100$ and $200 \mathrm{ppm})$ and ethrel $(50,100$ and $200 \mathrm{ppm})$. The experiment was laid out in Randomized Block Design (RBD) with ten treatments and three replications. The results of this experiment revealed that the plants that was sprayed with $\mathrm{GA}_{3} @ 200 \mathrm{ppm}$ evinced better performance for the production of plant height, number of primary branches, number of secondary branches, number of leaves, leaf area and leaf area index.

KEY WORDS : Brinjal, NAA, GA, Growth characters

HOW TO CITE THIS ARTICLE : Arivazhagan, E., Kavitha, A. and Kandasamy, R. (2018). Influence of plant growth regulators on yield and quality characters of brinjal (Solanum melongena L.) cv. ANNAMALAI. Asian J. Hort., 13(2) : 59-63, DOI : 10.15740/HAS/TAJH/13.2/59-63. Copyright@ 2018 : Hind Agri Horticultural Society 